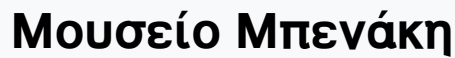

A Singular Antiquity: Archaeology and Hellenic Identity in Twentieth-Century Greece

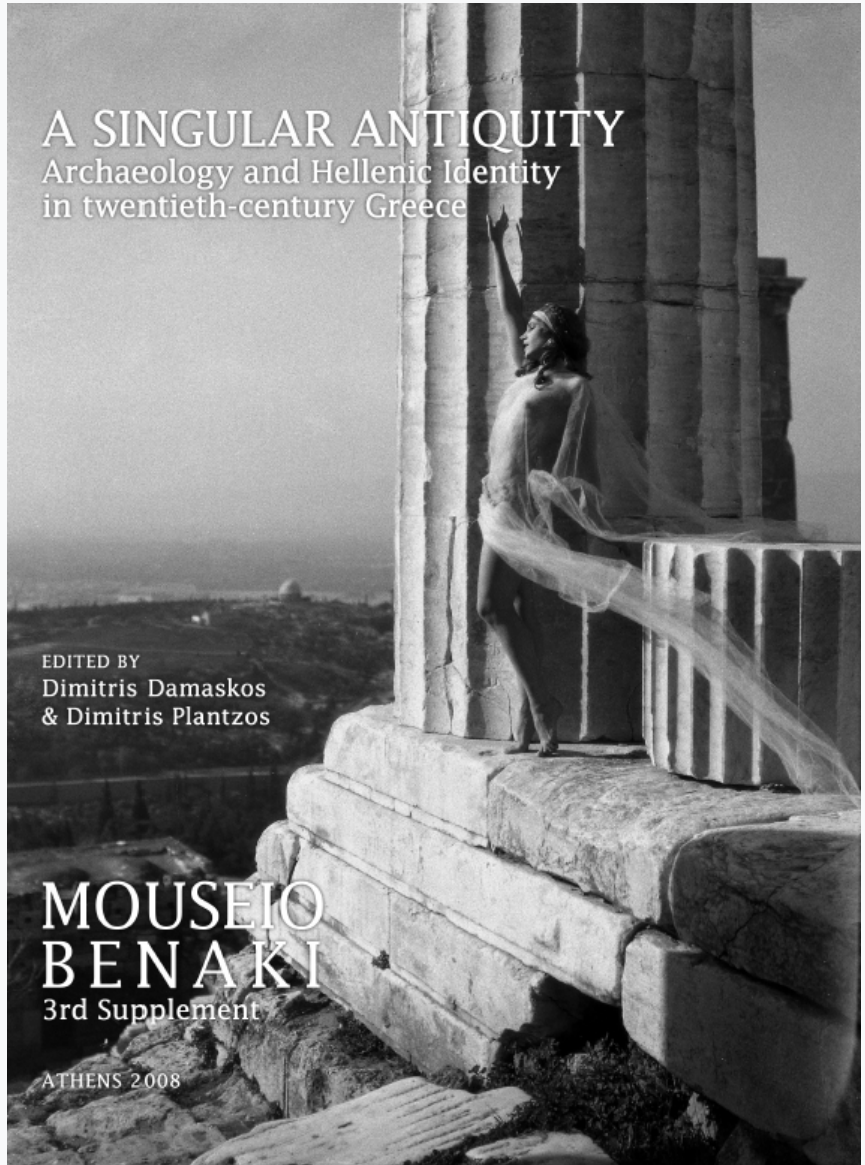

The archaeologist in contemporary Greek novel

Maria Diamandi

doi: $10.12681 /$ benaki.18066

Copyright $\odot$ 2018, Maria Diamandi

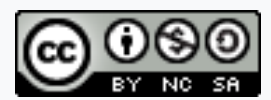

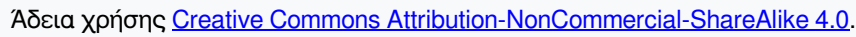

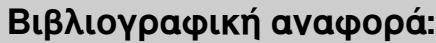

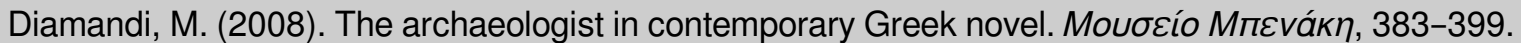

https://doi.org/10.12681/benaki.18066 


\section{The archaeologist in contemporary Greek novel}

'To yearn for your homeland while dwelling there - there is nothing more bitter'.

G. Seferis, Meres III (1977) 33.

IN 1833, IN ORDER TO PREVENT the sale of two, probably ancient, statues from Poros to Europeans, Makriyannis advised his compatriots: 'Even if they were to give you ten thousand thalers, do not allow them to leave your homeland. These are what we fought for.'

This well known quotation from the Memoirs of Makriyannis reflects the view his contemporaries held of Greece's ancient remains. ${ }^{2}$ Today it is a common belief that the remnants of their ancient glory were instrumental in the Greeks' decision to rise up against the Ottomans in $1821{ }^{3}$ that these remnants were what they 'approached' the Europeans with ${ }^{4}$ and secured their help; ${ }^{5}$ that with these they laid the foundation of their new state, ${ }^{6}$ that on these they formed their national consciousness; ${ }^{7}$ and that, in 1834 , for the sake of these remains of ancient glory, the Bavarian King of Greece, Otto, moved the capital from the commercial seaside town of Nafplion, to the then small and insignificant Athens. ${ }^{8}$ For as the legal scholar Georg-Ludwig Maurer, a member of Otto's Regency Council wrote: 'At your every step, at every glance to the side or towards the horizon, everything reminds you of the glorious days of the most celebrated city of the world. What king could choose another seat for his government, when he has in his hands the intellectual capital of the world? In this way did King Otto, after ample reflection, choose Athens. ${ }^{9}$ The final decision, therefore, was based on the symbolic value of the scattered remains of the glorious past, ${ }^{10}$ within the context of Western Europe. The Bavarian king himself was, in any case, the choice of Western Europe, and, according to the European ideological construction of the ' $\mathrm{New}$ Ancient Greece', ${ }^{11}$ he naturally preferred Athens. ${ }^{12}$ For the future of the new state, therefore, Athens was selected by virtue of her past. ${ }^{13}$ And the antiquity-loving Bavarians enacted the first archaeological law (1834) and founded the appropriate statutory institutions: the Archaeological Service (1834) and the Archaeological Society (1837). A chair of Archaeology was created in the Faculty of Philosophy in the newly established University (1837), and the professorship was assumed, at first, by the German archaeologist Ludwig Ross. ${ }^{14}$ Glorious antiquity was the foundation stone of the new state, which was considered to be the successor to this past. Therefore, the discipline which serves the ancient past - archaeology - became a pillar of the new state. The ideological construction of a glorious lineage requires material evidence, and tangible proof, in other words, ancient remains, and the specialists, the archaeologists who will discover them, protect them, describe them with accuracy, reconstruct them, study them, and disseminate them to the non-specialist public. ${ }^{15}$ In this context, archaeology becomes a very valuable discipline and a profession of benefit to the nation; the archaeologist becomes an invaluable scholar for the Greek state, and a professional with national impact.

This is the official discourse on antiquity, expressed by the king, his court, the Western-educated scholars, the politicians, the high-ranking officials, and the established institutions. On the other hand however, we read, for example, in Modern Geography (1791), with reference to Delos, that 'artisans from the neighbouring islands often come, as if to a quarry, and choose marble, here and there, from the scattered ruins'; ${ }^{16}$ and in Ross' Memoirs regarding the Athens of 1832 that 'many monuments of antiquity [...] 
lay ruined and their building materials are used as stones for construction or used for lime wash'. ${ }^{17}$ In any case, does not Makriyannis, in the quotation above, reveal a popular practice to be at odds with the official line? One can only wonder how widespread this was. For it was not only private citizens who differed in their view: Governor Kapodistrias (1828-1831) believed that 'we Neo-Hellenes have nothing of practical value to learn' from the ancients. ${ }^{18}$ Thus it seems that two diametrically opposed views co-existed regarding the antique past: one official, national, loudly trumpeted and largely imported, which saw in the grandeur of the past the guarantee of the future, and the other, basically private, vernacular, hushed, native, which used or sold the works of the past to survive in the present. ${ }^{19}$ One side 'purifies', restores, promotes the antiquities; the other side uses, crushes or sells them. The role of the archaeologist is swept along accordingly: for the former archaeologists are indispensable, and for the latter, probably useless.

In the pages that follow, and in the framework outlined above, we will examine the way the modern Greek novelists have dealt with the archaeologist. The field of study will be bounded chronologically and in terms of literary form. The two Athens Olympiads (1896 and 2004), milestones of international recognition of modern Greece as the legitimate and worthy heir to its ancient splendour, ${ }^{20}$ act as termini post and ante quem. The focus will be on the form par excellence for the creation of literary characters, the novel. ${ }^{21}$

Thus, in terms of the triangle, addresser-message-addressee, the first and the last have more or less been defined. The novelist (the addresser) and the reading public (the addressee) come from a specific period (between 1896 and 2004) and, for the most part, a specific place (Greece). Born of the intentionality of the addresser and responsive to the expectations of the addressee, the message - of which the archaeologist as a character in the plot is the conveyor - constitutes the object of our inquiry. The archaeologist, whether in ethographic/naturalistic prose or in other fiction, is not found in the novel by chance, nor indeed by necessity. Although this profession dates from as early as the formation of the new state, his inclusion is a conscious choice on the part of the writer who favours him because he/she believes an archaeologist will better convey the message than some other scholar or professional. Even when he is an imaginary character, he must appear real to be convincing; he must emerge from the historicity of the writer. ${ }^{22}$ There is, therefore, a fine balance between crea- tion and imitation, a careful blend of fictional elements and actual facts.

We have seen that the contribution of the archaeologist to the formation of the modern Greek identity, is by no means negligible. However, is he or she a character which interests the Greek novelist? After all, following the creation of the new state, the novelist realised that he/she carried the responsibility for the foundation of the new national literature, the creation that is, ${ }^{23}$ of those written works which will determine the essence of the nation. ${ }^{24}$ Thus, archaeologist and writer, each from their own perspective, contributed, in those years, to the shaping of the modern Greek identity. Would their common mission draw them close?

Surprisingly, my research bore fruit which can be counted on one hand. ${ }^{25}$ The five relevant works are: The Archaeologist [O apxaıonóyos] by Andreas Karkavitsas (1904),

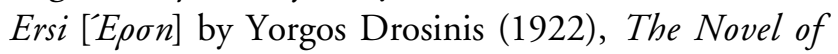

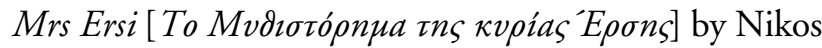
Gabriel Pentzikis (1966), The Throne Room [H Aidovoa cov doóvov] by Tasos Athanassiadis (1969) and The Guest [O $\varphi \imath \lambda o \xi \varepsilon v o v ́ \mu \varepsilon v o \varsigma]$ by Vangelis Hatziyannidis (2004).

\section{The Archaeologist}

The last prose work of Andreas Karkavitsas (1865-1922), ${ }^{26}$ The Archaeologist, was written in 1903 and published in 1904, eight years after the first Olympics of the modern era.

The story is simple. Two brothers, Aristodimos and Dimitrakis Morphopoulos, sons of the once rich and illustrious Eumorphopoulos family, in obedience to their late father's wishes, endeavour, each in his own way, to recover the former landed property of the family from squatters. Even their name has been debased and from Eumorphopouloi (the descendants of a man of fine figure), as their distant ascendants were called, they have become Morphopouli (the sons of a father of 'some', non-descriptive, figure).

The first-born, Aristodimos, labours to learn the language of his ancestor ${ }^{27}$ because 'tradition had it that, if they were great, it was because of their language' (1261). ${ }^{28}$ His dedication to books and his admiration for the ancestors is shared by three foreign scholars who excite his imagination and persuade him to excavate the land to bring 
to light the remains of the family's glorious past.

'Our riches are not above the ground [...] they are inside it. They have been preserved through time and years for us to find. And what joy [...] what glory, if they emerge back into the light of the sun! The foreigners will so be dazzled, that they will give us our patrimonial inheritance of their own accord' (1279).

In contrast, his brother, twenty-year-old Dimitrakis, believes that 'the past, no matter how glorious, brings no benefit to those who disdain the present and neglect the future' (1268). For this reason, he makes it his life's goal to oust the land grabbbers with 'strong arms and sharp nails' (1266), and to till the patrimonial fields, to cultivate them and give them life, to resurrect them and thus recover them.

Uprooting trees and destroying the estate, under the gaze of the three foreigners, Aristodimos commits himself to his excavation project, until he finds a full-length statue of a woman, which he recognizes as a personification of Doxa ('Glory'). 'It is our Glory - our undying Glory!' (1319) he cries. At the marriage feast of his brother and Elpida ('hope', the woman's name is presumably meaningful) he wants to show off his ancient finds, which have been assembled in the study along with the bride's embroidery, depicting the family's heroic history from Byzantine times to the ignominious Greek-Turkish war of 1897. 'The grace of the antiquities and the embroidery, placed side by side, conferred on them a family resemblance. You would think that they came from a single, great source, containing a myriad of converging springs' (1355). Naturally, the most marvellous find was the marble statue of Glory, which Aristodimos decides to prop against the trunk of a walnut tree.

'He embraced the statue, wanting to raise it. It was heavy, however; too heavy for his arms. But what can not be done through perseverance? After some tottering back and forth he finally managed to lift it in his arms. However, as soon as he tried to take two steps, he started to stagger and reached towards the wall to stay himself. But he only managed to grasp the edge of the embroidery. At the same moment, the massive statue leaned to the left, shattered one of the bookcases, and toppled with its adorer to the floor' (1355).

Thus the archaeologist meets an inglorious death, embrac- ing with his right hand, 'the disembodied head of Glory' and clutching, with his left, 'the edge of the embroidery' (1356).

In this allegorical, and cautionary, tale the signifier is the fortunes of the Eumorphopoulos family property, and the signified is the territorial aspirations of the Greek state. ${ }^{29}$ This is all the more evident if we examine the historical events of the period, the narrowly averted loss of Greek territory after the debacle of 1897 , and the burning issues of Crete $^{30}$ and Macedonia, filtered through Karkavitsas' commitment to the nationalist Megali Idea of a Greek state encompassing all ethnic Greeks. The Eumorphopoulos family is a metonymy for Greece, but which Greece? The extensive, Hellenic empire, which the advocates of the Megali Idea dreamt of and which would revive Byzantium. ${ }^{31}$ The parallelism continues. The squatter on the family's ancestral estate (Haganos) symbolizes the Turks who overthrew the Byzantine Empire, and the rustic with the expansionist designs (Petros Theomisitos) the Bulgarians who were then contesting a part of the Macedonian population. ${ }^{32}$

Aristodimos labours to 'resurrect ancient Greece, on the lands that were occupied till yesterday by the Turks' ${ }^{33}$ How does he do this? By learning the language of his ancestors and undertaking excavations. But this does not accord with the wishes of his father, who had fought in the revolution of $1821,{ }^{34}$ though it does meet with the approval of the three foreign professors, i.e. the Great Powers. ${ }^{35}$ In the end, in attempting to erect the statue of Glory, that is to re-erect the glorious ancient past, he loses his balance, falls, and is killed; ${ }^{36}$ not so much crushed by the heavy statue, which, in any case, is decapitated in the fall, not flattened by ancestral glory, but fatally compromised because he does not manage to hold onto the handwork of the illiterate Elpida. ${ }^{37} \mathrm{He}$ is doomed because he does not support himself with the vernacular art of the people. So it is not the weight of ancient glory which kills him. Despite his best efforts he does not have the strength, to lift it up and, in the end, he dismembers it. It is his failed attempt to support himself on the Greek folk culture which leads to his death..$^{38}$ It was the same culture which folk studies (laographia), the then new, Greek discipline, made its subject matter. And it was folk studies which attempted to validate the continuity of the race in scientific terms, and therefore justify the national aspirations. ${ }^{39}$ As the nationalist diplomat Ion Dragoumis (1878-1920) insisted, Greece could withstand the expansionist tendencies of its neigh- 
bours, and the scornful stance of the Europeans, by relying on the culture of its people, on its folk tradition. ${ }^{40}$ And this is also what Karkavitsas' The Archaeologist tells us. It was considered by many to be his weakest prose work, but for himself it was his most beloved. ${ }^{41}$

\section{Ersi}

The novel Ersi, one of the last prose works by Yorgos Drosinis (1859-1951) was published in 1922.42 Drosinis and Karkavitsas, his near contemporary, may have been separated by many things but they were also connected by others, such as writing for children, ${ }^{43}$ the ethographic/ naturalistic prose, the vernacular language, folklore, ${ }^{44}$ and a shared nationalist ardour.

The novel is romantic fiction with a nationalist orientation: the text develops as a series of exemplary dialogues between a model couple, against the backdrop of a picturesque Greek island. Drosinis, who for many years had served in positions of social responsibily, ${ }^{45}$ was writing, at an advanced age, a novel of sentimental education for young people.

Ersi is the wife of the archaeologist Pavlos Rodanos, a 'rare young man, notable for his figure and also his professional discipline' (65). ${ }^{46}$ The couple will spend six months, from the end of April to the end of October 1912, on an Aegean island, where Pavlos, thanks to the sponsorship of 'some rich islander from America' (28), will be working:

'And his work was to study the archaeology of the island and investigate its topography. [...] He was in an early stage [of his life]. It had been only three years since he had married Ersi. They had no children as yet. His wife's happiness was to help in each of his projects. And her greatest desire was [...] that they undertake an excavation together. What better opportunity then than that which had come their way? To spend the summer alone together, far from the heat of Athens, on a cool and charming island of the Aegean, and who knows, if chance should have it - make an archaeological discovery there!' (28).

And indeed, their life on the island passes idyllically: they exchange civilities, gallantries and trivialities, embellished, of course, with ancient words, lessons in antiquity and the verses of great poets. Pavlos, however, does not forget his duty, and towards the end of their stay, goes on an expedition with Ersi, to the uninhabited islet opposite, which he has identified with an island of antiquity, referred to in two scrolls. His goal is to discover the three statues of divinities, which, according to the sources, were to be found in a cave. In the end he finds the paraphernalia of a recent clandestine excavation, a letter to a merchant who was to sell the antiquities to an American buyer and clues relating to the illicit export of the statues. Returning from their archaeological sortie, the two young people are informed of the outbreak of the Balkan War, news to which the Epirote Pavlos Rodanos reacts with a cry 'unheard before, loud like a bugle' (222): 'You here - unrig your caiques, haul them ashore, pack away the nets of your fishing fleet. And we others, let us close our books, lock the drawers of our desks, leave our quills dry. And let us all venture together to create a Great Greece. For when we return, you will set forth your caiques to travel in wider seas, with our flag high; and we, instead of sitting outside the ancient temples and guarding them, will step inside, worthy of setting foot there, and we will worship them!' (222). It should be noted that Drosinis completed the novel in April of 1922, only four months before the destruction of Smyrna and the final wreckage of the 'Great Greece' which his hero envisioned.

The archaeologist, Pavlos Rodanos, for many pages the incurable admirer of his wife and perfect husband, the protégé of the Ephor of Antiquities, Kalliadis, ${ }^{47}$ and dedicated scholar of ancient sculpture, is finally exalted when he 'enheartens' and 'fortifies [the simple fishermen] for the great struggle' (223). For who else, Drosinis asks himself, could do this, if not 'the educated, cultivated man whose work was precisely the study of ancient history and ancestral glory, who else?' (223). Archaeology then, from being seen as a work that is 'selfish' and 'useless to humanity' (187), comes to serve the national good, and the archaeologist instead of remaining 'quietly shut up in his study with his head bent over books [...] like a miser of the intellect' (223), 'raises his body', 'holds his head high again' (224), and is transformed before the eyes of the common people into a national fighter ${ }^{48}$ and, in the eyes of his wife, into a 'man with all his might and splendour' (224). His personal dream to find the ancient sculptures has faded away but the national vision of a 'Great Greece' rises bright. ${ }^{49}$ The happiness of the couple is tested, but maybe happiness for the Greeks at large can be won..$^{50}$

Ersi, with roots in Constantinople and named for a 
mythical Athenian princess, and the Epirote Pavlos Rodanos, with his degree from Germany, have their permanent residence in Athens opposite the Acropolis. Drosinis, a Western-educated Athenian man of letters, ${ }^{51}$ still evoking the 'Great Idea' of a reborn Byzantine empire, also extols the capital of the Greek state, a state according to European models, which in that period came within reach of the much desired 'Great Greece of the two continents and the five seas'. At the time of writing the Balkan Wars (1912-1913) and World War I had greatly extended Greek territory, with the addition of Epirus, Macedonia, Crete, the islands of the eastern Aegean (not including the Dodecanese), western and eastern Thrace, and the western coasts of Asia Minor.

In 1925 Palamas characterized, on the one hand, Drosinis' novel as the 'poetry of archaeology', and on the other The Archaeologist by Karkavitsas as its parody. ${ }^{52}$ The issue for both writers in these specific works, however, remained the same: the liberation of those Greek regions still in bondage and the extension of the borders. What differs is the role of the archaeologist: catastrophic for Karkavitsas writing after the humiliating defeat of 1897 , and 'miraculous' (223) for Drosinis who was experiencing the optimism of three victorious wars. Although Ersi was widely considered an unsuccessful work, its creator believed that 'with regard to technique and linguistic form, it was [his] best prose work'. ${ }^{3}$

\section{The Novel of Mrs Ersi}

The 'ideal lover and spouse' (226), ${ }^{54}$ Pavlos Rodanos, is 'revived in flesh and blood' according to Seferis ${ }^{55}$ by Nikos Gabriel Pentzikis (1908-1993), ${ }^{56}$ in The Novel of Mrs Ersi, published in 1966.

Pentzikis uses (as Seferis again says), the 'framework', the whole 'panoply's7 from this 'novel, well known and loved by every romantic girl, by the departed and honoured academic and poet, Yorgos Drosinis' (53). The narrator of The Novel explains:

'As a student in the final years of high school, I had not only read the book already, I also created dreams of romantic love affairs with that text as the ideal. Why should these dreams not be realized! What hinders us from having the life we dream of? I believed that the scrutiny of these ques- tions, which occupied my deeply unsatisfactory life, found appropriate ground for investigation in the chronicle of last summer's impressions, as I was informed of them through socializing with Pavlos Rodanos himself, the young newlywed archaeologist of Drosinis' Ersi with whom a long friendship and close acquaintance connected us' (53).

In the final analysis, Pentzikis' revision is a subversive text which dispenses with the logic of narrative; ${ }^{58}$ it is neither a formal novel, nor a repeat of Drosinis' story - it is 'a dialogue with the novel genre in the first place, and also a dialogue with a specific earlier text'. ${ }^{59}$

In the first part, the narrator recreates snapshots from the summer holiday of Pavlos and Ersi in Kassandra, in Halkidiki in 1946, when, in his opinion, 'their enviable happiness, all the happiness which romantic love can offer, reached its zenith' (226). In the second part, he describes the dream which led to his estrangement from the Rodanos couple, and the appearance after four years, of Ersi, now a widow, who proposes that he write her story, to describe, according to her own narratives, the 'unique happiness she experienced at Pavlos' side' (227). The third part he dedicates to the 'representation of the past happiness' of Ersi, who embroiders the representation using the narrator himself as the needle, until the narrator-needle pricks her on the finger and draws blood. Ersi leaves, and from that drop of blood blazes a fire which burns 'everything [...] like an old stage set' (352). The narrator is saved and now 'in the real world' (375) undertakes a trip to Europe with his wife and their four children.

The man who in the beginning 'had no face that could win one such as Ersi' (57) through the fantasy of his meeting with Drosinis' characters, and his apprenticeship with this perfect couple, at the end of the book wins an Ersi. It is not clear whether this is a woman with whom he can enjoy the marital happiness which Drosinis described (in his case, without the complication of war), ${ }^{60}$ or whether this is a new story rather like the one told by Drosinis. ${ }^{61}$ The signified therefore, whether it refers to the marriage in Christ with a woman or to the text itself, is communication, that is the obliteration of solitude and the transcendence of the body. The Novel re-enacts the anguished adventure of an individual, of the narrator, until his consummation, as a man and as a writer, until he achieves his own truth, his own identity.

Let us remain with our character of interest: the archae- 
ologist Pavlos Rodanos, whom the narrator met, while still young and handsome, forty years after 1912, 'where he is placed by Drosinis' (57), holidaying with his wife Ersi in Halkidiki (and not on Drosinis' Aegean island), and who a few years later dies (a possibility left open by Drosinis who ends his text abruptly, with the mobilization for the Balkan Wars). In the few pages of The Novel which focus on 'the handsome and fine man with the broad learning and culture, with the exceptional morals' (226), we learn that he has seen the Nymph of the place in a hallucination. She inspires his archaeological pursuit, and he goes on to find the inscribed burial shrine to a maiden who 'with celestial acquiescence, continues to meet the living, after death' (316). Pentzikis' Pavlos Rodanos is, therefore, an archaeologist with metaphysical inclinations, ${ }^{62}$ who is not satisfied with the discovery of tangible finds, but 'pursues a transcendental meaning ${ }^{63}$ in his excavations. He is not a typical archaeologist who dates his findings and substantiates the developmental phases of ancient art, but a mystic who seeks to discern in the ancient marbles, 'what part of us is eternal, and what is vain and perishable' (65). In his opinion, ancient sculpture aestheticizes Platonic ideas and makes tangible the immaterial, which is not subject to the laws of time, and is, therefore, the eternal which he himself seeks.

Nonetheless, Pavlos interests Pentzikis more for his marital anxieties than for his archaeological pursuits, as, in spite of the great love he feels for Ersi, he is experiencing 'the dramatic role of a man in a difficult relationship with a woman, when she becomes a sovereign ideal, but at the same time does not cease to be flesh and blood, and as such, acts upon him directly' (290). ${ }^{64}$ Thus the archaeologist of The Novel, one of Pentzikis' best works, is principally a religious married man with an intense inner life, a painful consciousness of his loneliness, and a mystic sense of life. Focused on his existential anxieties, and inspired by a deepseated Christianity, he is like his creator, who perceived his own writing as 'an interpretation of the life of monks' ${ }^{65}$

\section{The Throne Room}

The Throne Room by Tasos Athanassiadis (1913 2006), ${ }^{66}$ published in 1969, was intended as the first part of a trilogy entitled My Mother Aegean, but this was never completed. ${ }^{67}$
With The Throne Room, published three years after Pentzikis' Mrs Ersi, we return to the classic novel, that is, to psychological realism in a historically defined context ${ }^{68}$ and to the prose writing of the generation of the thirties, of which Athanassiadis is considered one of the last representatives. Athanassiadis held key positions in the cultural affairs of Greece. ${ }^{69}$ I presume that his conformation to the literary establishment, represented by the generation of the thirties, was, on the one hand, in accordance with his public face; and, on the other, favourable to a widespread immediate acceptance, for example, of this particular work, which in its year of publication was awarded the National Book Award.

In spite of the troubled period - summer 1966 to the spring of 1969 - during which it was written, the novel does not reveal anything of the political disruption of those years, nor the repercussions on the lives and souls of the people. It transports us to the post-war atmosphere of an imaginary touristic island in the Aegean, where the promising son of the MP for the Cyclades arrives. He is returning from $\mathrm{Mt}$ Athos to his birthplace and a secular life, having divested himself of the monastic garb which he has worn for the last few years. A former SS commander is already there, appearing as a Swedish Croesus, but actually returning to the scene of his crimes, seeking forgiveness for the torture and executions he has been responsible for during the German occupation of the island.

In the 'throne room' of the title, where each of us will find ourselves at some stage, we must decide whether to lead a life of good or evil of which all human beings are equally capable. The signified is the final victory of good through genuine repentance for the evil already committed..$^{70}$ The young man has sinned because he abandoned life, and he returns, repentant, to the worldly life. The second, the older man, sinned because he took away life, and returns, repentant, to Christ, acting as a benefactor to the island which he himself had desolated, and saving the life of the orphaned daughter of a Cypriot fighter, whom he had tortured and killed.

Among the many characters that people the novel, and are representative of an era and a place (or so the author intends), there is an archaeologist: Sotiris Androulis, childhood friend of the young protagonist. Every summer he leaves the offices of the Ephorate in Syros, comes to the island and lives in a tent in the wilds. There he excavates 'often at his own expense' (36), ${ }^{71}$ to find the tomb of an an- 
cient priestess, which he finally discovers, under the gaze of the former German SS commander, now the island's great benefactor. Androulis lives for this ancient priestess, 'cut off from every human tie' (47). He does not dare to express his feelings for the most beguiling heroine of the novel, the daughter of the Cypriot fighter, and only when he is awarded a scholarship from the American School of Classical Studies to study in the US, does he decide to marry the sister of his childhood friend, who had been destined to him from childhood, but whom, until then, he had been avoiding.

What then, is the important decision which Sotiris Androulis makes, when it is his turn to find himself in the throne room? 'To see himself on the side of happiness, which he had scorned. No, he could not replace a person with a myth...' (48). And thus, instead of an unconsummated love for an ancient priestess, and a frustrated love for an irresistible woman, he chooses a quiet marriage to a reallife woman doctor. ${ }^{72}$ His role in the plot is small, and his decision in the throne room is small-minded. He is an extra in the crowded scene of the island community, a bit player next to the two anguished protagonists. The dilemma he is called on to face is equally insignificant and secondary.

At some stage the Mayor assigns him the responsibility of showing the island to the Swedish tycoon, because 'such a foreigner should not return to his country without having tasted the unique fruit called "Greek hospitality" (85). And the archaeologist who 'considered it a great honour to be the Swede's guide' (86), 'would leave nothing on their excursions without explaining it to them' (231).

For Athanassiadis who aspired to capture modern Greek reality, the archaeologist is the specialist who knows Greek civilization in all its phases, ${ }^{73}$ and knows at least one foreign language. Consequently he can assist and attract foreign tourists, for whom 'the blue vision of the Cyclades' combines the sea and a diffuse eroticism, with the civilization of Greece. The archaeologist then, the most suitable ambassador of Greek civilization, is placed at the service of tourism - which in the sixties had become the country's third largest source of income. ${ }^{74}$ Let us not forget these were the years of the tourist boom in Greece: in 1953, the first Xenia hotels were built in Greece, many of them, indeed, in places of archaeological interest. ${ }^{75}$ The annual performances of ancient drama in the ancient theatre at Epidaurus commenced in 1954, and in 1957 Olympic Airways made its first international flights.
The once otherworldly but always decorous, and later worldly, archaeologist, Sotiris Androulis - whose name indicates saving gallantry (soter $=$ saviour; andreia $=$ gallantry) a meaning albeit somewhat undermined by the diminutive ending of his surname - is a down-to-earth, patient and persistent excavator of the ancient past, ${ }^{76}$ the representative of Greek civilization, the voice of national values. Athanassiadis honours him, I think, for this latter quality, as he believed that Greece 'to preserve its identity [in the European Union], must [...] maintain unaltered its national values, must be transformed into an intellectual Greece [...] must crystallize its cultural contribution, whatever characterized it till now, the expression of its spirit and the ethos of its climate'. ${ }^{77}$ Thus, in Athanassiadis' novel, the archaeologist no longer pursues the territorial expansion of Greece, as the characters of Karkavitsas and Drosinis did, but celebrates the purity and prestige of its civilization, its intellectual hegemony.

\section{The Guest}

Vangelis Hatziyannidis (b. 1967)'s second book, ${ }^{78}$ The Guest, was published in 2004, the summer of the Olympic Games. In terms of the Greek novel, it could be considered some kind of settlement of a symbolic overdue account opened in 1896 with the first Olympiad, and a kind of reply, one hundred years later, to the antiquitystruck archaeologist of Karkavitsas.

The protagonist of the story, that is, the Guest, is a twenty-two-year-old undergraduate student of archaeology, and the narrator is the same character twelve years later, who now teaches archaeology at the University.

The young archaeology student, who had been the winner of a television general-knowledge quiz, is approached in 1991 by a strange group of three men and two women all in their forties, mostly artists. Wishing to delve into 'the great book of the Human Species' (24), ${ }^{79}$ they propose to him that, for a fee, he place himself at their disposal for fifteen days, so that they can scrutinize him and thus enrich their knowledge of humankind.

This experiment has been repeated at other times with different guests who interested the group for different reasons:

'The group kept a file with full details on each guest. They 
recorded there not only whatever had been said at the meetings, but also, opinions, comments, judgements. Everything they wanted to learn; the aspects they had to study; how they would close in on what they sought. How they would weave their nets. And, naturally, the conclusions. The substance. They wrote it all down. In this way, they managed to capture and record [...] the composition of each individual, the essence; and this would remain forever protected in their notebooks. The aim was in time to compile [...] a "human library", with each volume containing the very essence, the blood of real-life individuals. Chosen people. Hand-picked guests. A rare hoard' (203).

In the case of our student, the particular characteristic which had piqued their curiosity, was his love of learning, 'the conceit of knowledge, the craving for knowledge, the germ of knowledge, the absurdity of knowledge. [...] Basically they wanted to determine what damage a mania for knowledge can inflict on the deeper personality' (215) of such a young person.

The student accepts the invitation and is put up at a secluded hotel, which belongs to the leader of the group. After fifteen days, the programme of 'study and acquaintance' (204), which includes daily meetings, conversations, questions and confessions, is completed, and the student leaves, having elicited the guilty secret which weighs on his hosts: the accidental killing of the previous guest. Three months later, the student makes a statement to the police of all he knows of the crime and then leaves to begin postgraduate studies in Italy. There is a trial, the head of the group is sent to prison, and the group breaks up.

The subject of the novel - and furthermore, the objective of the 'gang' - is knowledge, and indeed, forbidden knowledge: ${ }^{80}$ its nature, its boundaries, its might, its black holes, its morals. ${ }^{81}$ Aiming to learn the boundaries of the knowledge of their knowledge-loving guest, the group, that seeks the exclusivity of knowledge, offers him 'a small, tempting morsel of knowledge' (215): they reveal to him an unpublished, tenth-century codex, the sole testimony about an unknown ancient goddess of secrets. But in the final analysis, they do not discover the boundaries of his knowledge; they are unaware of the fact that he finds access to forbidden knowledge, learns their great secret, the secret crime, of which he informs the police, and the band, of necessity disperses, having lost their secret, the power of exclusive knowledge. ${ }^{82}$
From this tough and dangerous game ${ }^{83}$ the archaeologist-player, in the end comes out the winner. From this unethical experiment, the student guinea pig $^{84}$ emerges unscathed and ethically intact. He was unprepared for the question regarding the ancient goddess, which the leader of the group asks him. However the game, in the final analysis, was not judged on his archaeological knowledge, which in this case proved lacking. Certain qualities of his character, such as observational skill, ${ }^{85}$ sharp-wittedness, sangfroid, curiosity, alertness, the ability to make connections, soundness of judgement, ${ }^{86}$ daring, restraint, ${ }^{87}$ and a solid ethical basis, ${ }^{88}$ plus naturally some luck, ${ }^{89}$ were what enabled him to emerge as the winner and master player, one against five unscrupulous adversaries.

It is not impossible that these qualities had been honed or may even have emerged from the pursuit of his archaeological discipline. After all, its scientific method is based on the collection of data (observational skills), examination of the collected evidence (curiosity, alertness), classification and combination of this evidence (sound judgement, ability to make connections), not coming to hasty conclusions (sangfroid, restraint) and so on. In other words, these virtues may have been sharpened by or have emerged from the curriculum attended by any fourth-year student at a University, if not specifically of an Archaeology Department. The protagonist himself confesses: 'From the time I settled into the hotel, I ceased to see my entanglement in this situation as an unlikely adventure, and treated it like an assignment I was obliged to complete' (58). Why should he not mean a university project? The Guest succeeds in the end, not because of his admirable learning, but owing to his personality, his overall brilliance and the manner in which, despite being unprepared, he approached the strange situation in which he found himself.

On the other hand, we know (because the writer deliberately informs us) that our hero is a final-year student of archaeology when he lives through this story, and a professor of archaeology when he recounts it. As he himself says, the memories of the strange hospitality, 'buried deep, but protected, as was Pompeii by the lava [...] I dredge up, piece by piece. With a sieve and a small brush' (81). 'And the scattered pieces [...] broken off and fragmented, highlight the details more distinctly than the whole' (83). The archaeological method therefore, proved useful: it helped him fill in the blanks of memory, and complete the 'reconstruction' (81), that is, the narration. He emerged un- 
scathed from the experience, because he was not blinkered by a strictly archaeological way of seeing things; however, he narrates the story thanks to the archaeological method of reconstruction.

To summarize: our scanty harvest, of five unequal and very different novels, covering the period of just over one hundred years between the two Athens Olympiads, is more plentiful at the beginning and around the middle of the twentieth century, with nothing in between: two works from the first twenty years, two from the sixties, and one from 2004. Consequently, the answer to our initial question is that few modern Greek prose writers have chosen the archaeologist as a literary character and the few novels which feature one are not necessarily the most significant, nor the best loved. It seems that the archaeologist did not attract modern Greek prose writers and thus there is no stock type for the role.

Four of the five writers (Karkavitsas, Drosinis, Athanassiadis and Hatziyannidis) lived in Athens, ${ }^{90}$ although, with the exception of Drosinis, they were not born in the capital. Living in the shadow of the Acropolis, they could more easily, I presume, take an interest into the archaeologist, unlike Pentzikis, who lived in his birthplace 'Mother Thessaloniki', as he himself used to say, ${ }^{91}$ a city of Byzantine antiquities. And I would suggest that Pentzikis' peculiar and private archaeologist is quite different from the rest.

Let us start with the common points between the five archaeologists:

a) Their gender is always the same: male. I do not know when women began to dominate archaeology in Greece, but in any case, though these five heterosexual male writers have central heroines in their works who inspire love, they do not choose women archaeologists. Why does the woman archaeologist not become a muse of erotic passion? Even Pentzikis who had an archaeologist wife and who began writing The Novel on their summer holiday, as newly-weds, in Kassandra in Halkidiki, gives a male face to archaeology and a female face to love. On the other hand, the small number of archaeologists in the Greek novel reflects, I imagine, the remote degree of intellectual kinship which prose writers felt they had with them.

b) The five fictional archaeologists defer to a higher intellectual authority which is always foreign. In Karkavitsas three foreign professors instigate and oversee the excavations; in Drosinis a foreign journal approves and publishes the archaeological study; in Pentzikis, we have the enig- matic Ruit Hora - Ephor of Antiquities, Kalliadis, who 'symbolises foreign influence in Greece'; ${ }^{22}$ in Athanassiadis the archaeologist is given a place abroad to pursue his postgraduate studies; in Hatziyannidis, thanks to his knowledge of the American society Phi-Beta-Kappa, the final-year archaeology student is promoted to Guest.

In addition to these not insignificant constants, over the course of 108 years the archaeologist as literary figure was transformed in relation to the historicity of each author.

At the beginning of the twentieth century, in the period of national aspirations, his academic qualities, so useful for constructing an indisputable ethnic continuity, necessarily involve him in national issues. For the prose writers of the generation of the 1880s he is important. For Karkavitsas, who never ceased to highlight his provincial origins, the pre-scientific antiquarian is condemned because he damages the national interests, whereas, by contrast, Drosinis, a typical Athenian man of letters of the period, depicts his bourgeois patriot-archaeologist as a model for promoting the national interests. Naturally, both archaeologists, constructs of two writers who never renounced their ethographic/naturalistic writing, nor the didactic mission of the author, are schematic and one-dimensional: the one disastrous, the other a saviour.

It seems that war (the Asia Minor Catastrophe, World War II, the German occupation, the Civil War) is not a time for archaeologists, who only reappear in the Greek novel forty years later, in the sixties ${ }^{93}$ - at a time when the Greek landscape was attracting tourists, and Greek civilization was once again attracting admirers. The torch had now passed to the generation of the thirties, albeit, not its chief representatives: ${ }^{94}$ the enterprising - in a Greek context - Pentzikis, from the generation's avantgarde Thessaloniki wing, and a latecomer to its Athenian branch, Athanassiadis. The former creates an introverted, married, religious archaeologist-intellectual; the latter an extroverted, ${ }^{95}$ unmarried archaeologist-guide. Neither of them is any longer committed to the expansion of Greek borders, as their fictional colleagues from the early twentieth century had been.

After 1974, Greece hastened to recover from the dictatorship, modernizing, and Europeanizing, so for the next thirty years there would be no need to fall back on its ancient past. In August 2004, the month, that is, of the Olympic Games, Hatziyannidis' The Guest was published. With the games, Greece was, in a way, justified in under- 
lining the special nature of its national identity, and the archaeologist, who is no longer called on, either to prove it, or promote it, becomes a little less of an archaeologist. Athens, measured once again against her classical past, organizes a celebration, and he, the archaeologist, measured against five peculiar people, takes part in a game.

\section{NOTES}

* I would like to thank Anastasia Caramanis for the translation of my paper.

1. Makriyannis 1947, III.a. In any case, it should be noted that at the Third National Assembly at Troezen (1827) the sale and removal of antiquities from Greek territory, had already been forbidden (Petrakos 2004, 5).

2. 'A work such as Makriyannis' [...] is [...] the conscience of an entire people [...]' (Seferis 1974, 263).

3. 'The War of Independence was undertaken in the name of the ancient past, indeed, of classical Greece' (Politis 1997, 20). That is to say, in the Greek Struggle the ancient past played the role of a 'causa belli' and a 'rallying cry' (Dimaras 1977, 127); or 'idea and instrument' (Kremmydas 1996, 25).

4. Kremmydas 1996, 29; Hamilakis 2007, 76.

5. Calotychos 2003, 237.

6. At a meeting of the Archaeological Society on the Acropolis in 1838, Iakovos Rizos Neroulos stated, 'Gentlemen, [...] to these stones we owe our political rebirth' (Kokkou 1977, 16). Thus, in their estimation of the ancient past, the 'unhewn words' of the illiterate fighter Makriyannis, find common ground with the formal speech of the cultured Phanariote.

7. For the genesis and spread of Greek national consciousness, cf. Politis 1998, 31-35; and Peckham 2001, 13-17. On the eve of the Struggle, the Greek-speaking 'devout, orthodox Christians', as Cosmas of Aetolia called them in about 1779 (Menounos 1979, 22; for the chronology of the Teachings, see Menounos 1979, 302; republished in Politis 1998, 33 n. 3), no longer define themselves by religious criteria, but on the basis of their descent from the ancient Greeks. To cite a few examples: in 1791, the authors of Modern Geography, refer themselves as 'the descendants of those celebrated [ancestors]', meaning the ancient Greeks (Filippidis \& Konstantas 1988, 148); in 1797 the Balkanist Rhigas begins his New Political Administration with the phrase 'The people, descendants of the Greeks' (Rhigas 1994, 15); and Makriyannis, before the War of Independence, refers to his compatriots as 'Romioi' [from Romaioi (Romans), that is citizens of the (Eastern) Roman Empire, i.e. Byzantine Empire, as the people we call 'Byzantines' called themselves]
A simple coincidence you might say. And maybe you would be right.

\author{
Maria Diamandi \\ Benaki Museum \\ diamandi@benaki.gr
}

whereas after the declaration of war, he calls them 'Hellenes', encompassing the notion of the ancient past (Hamilakis 2007, 77 n. 10).

8. What Ludwig Ross, the archaeologist and later, Professor of Archaeology at the University of Athens, writes on his arrival in Athens in 1832, is revealing: 'What a dire vision of desolation! A wretched heap of ruins, some low huts, full of cracks, rebuilt any old how, the proud remains of Antiquity, a few ruined churches and mosques, a few better maintained houses or new structures, which have started being built, and a dozen or so, scattered palm trees or cypresses' (Ross 1976, 48; republished in Koumarianou 2005, 313).

9. Maurer 1976, 478; republished in Koumarianou 2005, 307. It is worth noting the profound difference between the full-page description of Athens by the Bavarian legal scholar, rich in archaeological details, and the corresponding short report contained in the Greek work Modern Geography, 'perhaps the most penetrating text bequeathed to us by the Greek Enlightenment, in which there is an attempt to define the Greek world, in relation to a consideration of the historical framework' (Filippidis \& Konstantas 1988, 10*): 'Among the ancient beauties of Athens, the temple of Athena, a [monument] worthy of seeing and admiring, had been preserved intact up until the end of the last century. [...] Many other remnants of its past splendour, and inscriptions carved on stone, had also been preserved' (Filippidis $\&$ Konstantas 1988, 154). The invocation of 'ancestral history and glory' (Rhigas 1968, x), which is the aim of the texts of the Greek Enlightenment, chiefly from the end of the 18th c., is certainly not based on archaeological substantiation. In 1796, for example, A Concise Archaeology of the Greeks, was published in Vienna: it talked of antiquity, but not at all of archaeological findings (Sakellariou 1796). At this time, the word 'archaeology', still meant principally the knowledge of antiquity.

10. Without underestimating the, in any case, distinct symbolic value of the monuments of the prominent Acropolis, which was the 'topos par excellence of a European logos about Hellenism' (Leontis 1995, 41; emphases in the original), let us keep in mind that in the newly formed, geographically limited state, major archaeological sites of the classical period, such as Olympia and Delphi, had not yet been systematically excavated, 
and thus their full extent had not been uncovered. The buildings of Olympia, which had been knocked down by an earthquake, had been covered by the alluvium deposits of the Alfeios and Kladeos rivers [in 1829, a hasty excavation of the temple of Zeus, was undertaken by the French archaeological expedition of the Morea (Peloponnese)] while, on top of the ruins of the temple of Apollo at Delphi, the village of Kastri had been built. In any case, at that time, even 'the monuments of Athens [...] were either invisible, covered entirely by houses or cultivations [...], or had been incorporated into the medieval and Turkish buildings, as [had been] the monuments of the Acropolis' (Petrakos 2004, 20-21). In 1835, 'when the Acropolis came into the jurisdiction of the Archaeological Service [...] it was a large cemetery [...] of animals and people who had lost their lives in the last siege' (Petrakos 2004, 24).

\section{Yakovaki 2006, 447.}

12. 'Both a birthplace and a paradigm, Athens becomes at the same time, a historic city from which everything began, and an ideal to which everything tends', Yakovaki 2006, 440.

13. Politis 1998, 76; Leontis 1995, 27-28; Hamilakis 2006, 106.

14. We do not know how many of the graduates of the Faculty of Philosophy worked as archaeologists. In the period between 1837 and 1890 (Lappas 2004, 362), the Faculty was the second to last choice for students, after law and medicine, which offered greater potential for professional and social advancement. It seems that the majority of Philosophy graduates were channelled into the teaching profession as philologists, cf. Lappas 2004, 369; 381.

15. Hamilakis 2006, 100; for the work that was undertaken by the Archaeological Service, cf. Petrakos 2004, 20.

16. Filippidis \& Konstantas 1988, 233.

17. Ross 1976, 47; republished in Koumarianou 2005, 312.

18. Politis 1988, 76 n. 5; Petrakos 2004, 14.

19. Cf. also Tziovas 1995, 340.

20. The reasoning of Dimitrios Vikelas when, as representative of the Panhellenic Gymnastics Association at the International Conference in Paris in 1896, he proposed that the first modern Games be held in Athens, was typical: 'I asserted Greece's rights with regard to the revival of a Greek institution. It is true, as Victor Hugo said, that all civilized nations have ancient Greece as a common 'foremother', but we have her as a mother. We are, in a way, the uncles of other nations. In this is our only pre-eminence. [...] On this basis do we assert the right to inaugurate the re-established Olympic Games on Greek ground' (Vikelas 1997, 132). The following evaluation of the 2004 Olympiad, which the Prime Minister, Kostas Karamanlis, called a 'national matter' is also typical: 'Greece's organization of the 2004 Olympic Games proved that the Greeks, when they want to, can excel. Although the financial cost was high, the aesthetic result was impressive. [...] The elements of the Greek picturesque and the love of the ancient past, were incorporated without discord, into the whole spectacle' (Veremis \& Koli- opoulos 2006, 16-17). According to the two historians, therefore, Greece stood worthy of its ancestral glory, and the obvious adulation of the antique past did not annoy, as it was presented attractively, and thus became acceptable.

21. 'The real worth of a novel is the creation of characters', writes the 'fervent supporter' of the form (Vitti 1977, 311; Theotokas 2005, 493).

22. Cf. also Ricoeur 1990, 69-70; 74. The theorist's idea is confirmed by the writer of historical novels, Rea Galanaki 1997, 16: 'Although a writer draws on other people and times, he always writes about his own life and time. It would be unnatural or even impossible for him to operate in any other way as a creator.'

23. Voutouris 1999, 283.

24. Apostolidou 1995, 15.

25. Lambropoulos (forthcoming) comes to a similar conclusion in his survey of the Acropolis in Modern Greek literature. To cite an impressive example (although from an earlier period than our study): Alexandros Rizos Ragavis (1809-1892), Professor of Archaeology for twenty years (1844-1867) at the University of Athens, and active excavator, does not include a single archaeologist, either real or fictional in the more than 1350 pages of his published prose. In any case, his 'delightful and useful' stories did not have Greek story lines, and neither did they aim to show 'a collective vision or a common national stockpile' (Tziovas 1999, 58), as the ancient past was for the

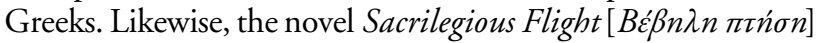
(Athens 2003) by Vassilis Gouroyannis refers to archaeologists merely as members of an academic community, and not as literary characters, and accordingly I have decided not to include it in this paper.

26. For Karkavitsas' biographical details I have relied on Sideridou-Thomopoulou 1959; Tsouras 1990; and Stavropoulou 1997. Here I would like to warmly thank my friend Christos Boulotis, who put at my disposal his unpublished paper on Karkavitsas' The Archaeologist, which he presented at a conference organized by the French School of Archaeology in Athens. The text proved invaluable for my study.

27. One of the first to write prose in the demotic, the contemporary Greek spoken by the people, as opposed to the archaizing, constructed katharevousa, which attempted to cleanse the 'pure' Greek tongue of later or foreign influences (Stavropoulou 1997, 185-86; Sahinis 1957, 154), Karkavitsas actively participated in the 'language confrontation' as a founding member of associations of a linguistic/educational nature, such as the ' $\mathrm{Na}$ tional Tongue' (1904) and the 'Educational Society' (1910). At the end of the 19th c. and in the early years of the 20th c. demoticism, as a reaction against the 'intellectual, social and national suffocation' which prevailed in the country, particularly after the defeat of 1897, was a diverse intellectual movement which rallied people of various ideologies and political views. For nationalists such as Karkavitsas, the language issue was a national matter, the demotic was the proof of national continuity and unity 'within and, principally, outside the Greek borders', and demoticism carried the thrust of the national struggle (Sta- 
vridi-Patrikiou 1976, lxxxvi).

28. I used the 1973 edition (Karkavitsas 1973). The page numbers are noted in parentheses after each extract.

29. Politi 1994, 48 (= Politi 1996, 134).

30. Karkavitsas took part 'as a volunteer in the Cretan Expeditionary Force' in 1897, and 'in the battles to recapture Thessaly' in 1898, Tsouras 1990, 1199.

31. 'The Empire [...] was the "national state" of Greek dreams outside the Greek borders' (Skopetea 1999, 28). The nationalist Ion Dragoumis, is clear: 'The small Modern Greek state [was] formed by an outbreak of panhellenic impulse when the national consciousness in the form of the Great Idea spread through the people, that is, with the nostalgic remembrance of the Byzantine state', Idas 1914, 5.

32. The underhanded villager, Petros Theomisitos, whom the Morphopouloi protected, Christianized and civilized (63), represents the 'ungrateful' Bulgarians, the 'last age-old enemies of the Greeks' (Skopetea 1999, 17; 15); after 1880, 'the Bulgarian becomes enemy number one in the national consciousness, and this emphasis becomes even more noticeable with the Macedonian struggle' (Dimaras 1977b, 404).

\section{Dromazos 1946.}

34. The novel takes place in 1897 or soon thereafter, when memories of the repercussions of the defeat, were still fresh (cf. Politi 1994, 50 [= Politi 1996, 147]). The father of Aristodimos and Dimitrakis, Andreas Eumorphopoulos, recovered part of the patrimonial estate from the squatters, just as the newly formed state which resulted from the struggle, had liberated only a part of Greek lands from the conquerors; Stavropoulou 1997, 204.

\section{Politi 1994, 49 (= Politi 1996, 142).}

36. Similarly, Yorgos Souris who, according to Palamas, expressed the 'folk spirit of the urban centres' (Apostolidou 1995, 33), writes in 1882, that: 'Whoever seeks the monuments of a classical education,I whoever unearths the statues of no one,I whether he is called Koumanoudis or Kavadias, I will be buried with the statues, alive.I So many marbles and archaeologists will be missingl and the nation will no longer feed on old glory' (Dimaras 1977b, 404).

37. Elpida, with a Turkish father and a Greek mother, embodies the dual aspect of the native folk tradition, Peckham 2001, 135.

38. Karkavitsas systematically gathers material for his folklore studies, Stavropoulou 1997, 190; 188 n.12; cf. also Spyridakis 1951; and the demoticism to which he adhered was always accompanied by the discovery of folk tradition. 'Modern Greek folk culture was regarded as a vast goldmine, where Greek scholars, like other gold diggers, zealously searched for nuggets of the glorious past' (Kyriakidou-Nestoros 1978, 25).

39. 'Laographia', as the study of folklore was named by its founder, N.G. Politis in 1884, takes the Greek people and their culture as its subject, attempting to define the national identity and to substantiate the continuity of the Greek people, Kyriakidou-Nestoros 1978, 15; 18; 46. In 1908, Karkavitsas became a founding member of Politis' Laographic Society, Tsouras 1990, 1200.

40. Stavridi-Patrikiou 1976, lxxxvii. Dragoumis himself says of the demotic tradition, that it was 'the living source of every form of Greek culture from when the first Greek was created on Greek soil to the time when he will disappear from the face of the earth [...] following this tradition we rise to meet our psyche, the true source of the Modern Greek life' (Idas 1914, 19-20).

41. He himself states this in a letter from 1905: 'I like The Archaeologist best of all my works. It says something to my unhappy and sanctimonious people, in order to put them on the path to truth, the path of God. For us here - you know this, I believe - it is not yet time for idle songs. We must also indoctrinate' (Stavropoulou 1997, 205-6 n. 37).

42. For Drosinis' biographical details I have referred to Chrysogelou-Katsi 1997. 'Sentenced, for over half a century, to the schoolroom abuse of his goodly number of poems' (Savvidis $1989,155)$, Drosinis is better known today as a poet.

43. In the last years of his life, Karkavitsas methodically wrote children's stories for primary school readers (Thomopoulou-Sideridou 1959, 207) and Drosinis, in his capacity as Department Head of Arts and Culture in the Ministry of National Education and Religious Affairs, published school textbooks (Golfis 1951, 1339).

44. Drosinis, one of the founding members of the Greek Laographic Society (1908), also collected folkloric material, which he utilized in his texts; Chrysogelou-Katsi 1997, 100-1.

45. Apart from his position in the Ministry of Education, he had also undertaken the editorship of a number of journals, which included the well-known Estia and Ethniki Agogi, and had served as lifelong secretary to the Association for the Dissemination of Useful Books. Drosinis, 'a central figure of a particular time' (Haris 1951, 1330), represented the generation of the 1880s, 'a generation of humanists with an impulse towards every form of enlightenment' concerned with the education of children and the cultivation of the people; Dimaras 1951, 1372 .

\section{I used the 1998 edition (Drosinis 1998a).}

47. For the character of Kalliadis, Drosinis was inspired by the archaeologist Georgios Sotiriadis, of whom he wrote: 'We were bound by a close friendship which dated from the time of Estia and our mutual struggle for the Greek identity of Macedonia', Drosinis 1998b, 301. It appears that the world of Greek archaeology (both in terms of people and bibliography) was not unknown to Drosinis; Papakostas 1998b, 17.

48. Believing in the 'need for the reversion of citizens to arms, and for training them in target shooting' (Papakostas 1998a, 17), in 1907 Drosinis published the book Target Practice for the Nation and was involved in the foundation of the Target Shooting Association.

49. When they leave the island, Ersi says to Pavlos, 'Turn 
around to see our lost dream for the last time' and he replies 'Enough of the dreams of the past, the fallen marbles of the temples, the shattered vessels of the tombs - now we are going towards the great dream of Life, the Resurrection!' (225).

50. Alexandraki 2003, 118.

51. After studies at the Athens Law and Philosophy Faculties, Drosinis went on to study in Leipzig, Dresden and Berlin.

52. Chrysogelou-Katsi 1997, 108.

53. Papakostas 1998a, 44; Papakostas 1998b, 16.

54. After the 2005 edition, N.G. Pentzikis, The Novel of Mrs

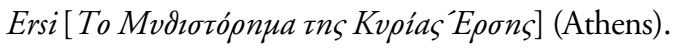

\section{Seferis 1987, 34.}

56. Pentzikis' biographical details are drawn from his autobiographical note in Papatriantafyllopoulos 1993 and the one in the recent reprint of his novel.

57. Seferis 1987, 34-35.

58. Cf. Varikas 1980, 128.

59. Alexandraki 2003, 13.

60. 'Mrs Ersi is my wife, but also the distance that separated us when I wrote the book, and also a thousand things which separated us within our union,' Pentzikis confided to Tsagarousianos 2007, 59. Pentzikis started to work on the text of The Novel in the summer of 1950, while summering with his archaeologist wife in Halkidiki, see the end page of his novel.

61. Alexandraki 2003, 16-17.

62. Cf. Pashalis 1988, 113; 115.

63. Alexandraki 2003, 131.

64. 'The story of the happy common life of a couple [in Drosinis' Ersi] is transformed into the story of the lonely moments and the inner conflicts of the couple in The Novel of Mrs Ersi (Alexandraki 2003, 127; cf. also Voyatzaki 2001, 182).

65. Fostieris \& Niarchos 1983, 135.

66. For Athanassiadis' biographical details I consulted Stavropoulou 1992.

67. Stavropoulou 1992, 62 n.13.

68. Athanassiadis aspires for his 'work to survive as a fictional chronicle', 'a faithful witness to the peoples, customs, events and ideas of a time' (Niarchos 1976, 16-17; republished in Stavropoulou 1992, 60; cf. also Moschos 1976, 134-35). Nonetheless, the reader does not pick up either the feeling of the period, or get a sense of the writer, cf. Argyriou et al. 1973, 172-73; 175; Sahinis 1979, 89; 91.

69. From 1945 to 1972 he held important administrative positions in the National Theatre, from 1978 to 1980 he served as President of the National Book Award Committee, and member of the Administrative Council of the Greek National Opera. In 1986 he was voted a member of the Academy of Athens.
70. Cf. Stavropoulou 1992, 68; Mamalaki 1978, 543. The writer himself confesses that in his works, he 'prefers difficult types, vacillating between good and evil' which coexist in every person (Troupaki 1984, 66).

71. After the 2005 edition, T. Athanassiadis, The Throne

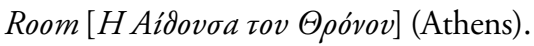

72. The 'positive', and in the end, 'down to earth' Androulis, 'represents the proper model for a young person, who develops harmoniously: intellect, reason and emotions have a balanced effect on his disposition' (Mamalaki 1978, 544).

73. Androulis is asked to show the 'church of St Polydoros, which was one of the most characteristic of Cycladic architecture' (42). The archaeologist's knowledge of church art is probably not irrelevant to the characterization of The Throne Room as 'a living expression of the Greek and Christian culture of our time' (preface of the novel), a spirit which, as is well known, was promoted by the military junta. This dual Hellenism-Christianity appears in any case, explicitly in the novel, with the phrase 'Christian and Greek am I!' (130) which, as we learn, St Polydoros called out before meeting a martyr's death on the gallows. Could this be a 'progressive conservative' writer (Karantonis $1977,315)$ sliding towards a particular idea of the Greek nation, or just an echo of the pervading atmosphere of the time?

74. 'In 1951, tourism was fully integrated into the agenda for the reconstruction of the country and EOT [the Greek National Tourism Organization] was re-established'. The touristic development of Greece was so rapid that already 'in 1966, the Bank of Greece estimated that in the next ten years, the income from tourism would surpass the total income from shipping and remittances from emigrants', that is, the sum total of the two most lucrative sources of income, Marmaras 2007, 20-21; 27. The dictatorship would later offer incentives for investments in tourism, Veremis \& Koliopoulos 2006, 457.

75. Nonetheless, the first director of EOT's Technical Services (Haralambos Sfaellos), as well as his successor (Aris Konstantinides), who in the fifties undertook the project for the design and construction of the model Xenia hotels, chose locations for these chiefly on the basis of access by road and pre-existing business activity, Marmaras 2007, 24. For them, antiquities only took third place, after climate and landscape, in Greece's list of attractions for foreign tourists, or so it seems from a text by Konstantinides (Konstantinides 1987, 200): 'It would not be an exaggeration to say that Greece is one of the most beautiful countries in the world. It has sun [...] landscapes divine in their beauty [...]. And the Greek land has, finally, history, with monuments from some of the most significant moments of humankind, and the world.'

\section{Moschos 1976, 113.}

77. Niarchos 1976, 14. Kayalis 2002, 337 rightly notes: 'The "intellectual nationism" of [the generation of] 1930 [to which Athanassiadis belonged] views the nation as an abstract metaphysical being, beyond the process of reason, and links nationality and the authenticity of art with a deep exploration of the Greek geoclimatic specifics [...] transferring the aspirations of the "national rebirth" from the area of territorial expansion to 
that of the cultural hegemony of Hellenism'.

78. I drew Hatziyannidis' biographical details from press clippings which the author was so kind as to send me, and for which I thank him warmly.

79. I use the 2004 edition, V. Hatziyannidis, The Guest [ $O$

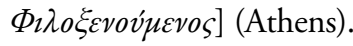

80. 'Secrets rule our lives' (143), says the leader of the group to the 'guest'.

81. Hatziyannidis says, typically: 'Awareness and knowledge are [...] a source of unhappiness; a person is always like a child who likes to open cupboards and drawers' (from an interview to G. Karouzakis in the lifestyle magazine Lifo, 25 January 2007, 16).

82. 'The whole work hinges on the significance of the inscrutable and the secret, of the joy of pulling back the cloak of mystery, and illuminating that which is in the dark' (see E. Kotzia, I Kathimerini, 24 October 2004, p. 6 of the cultural feuilleton of the Sunday edition).

83. 'An unpredictable game, since the main pawn was a living and self-willed being' (98).

84. 'They would use me, probably, as a guinea pig. They would subject me to trials of different sorts' (90).

85. 'I observed them as carefully as they observed me. That this was happening did not, of course, even occur to them. The difference was that I was not paying them, whereas they were paying me. I studied them, I analysed them' (94).

86. In a letter which he sends to the Guest twelve years later, the leader of the 'gang' confesses: 'You had a wonderful mind and, although young, infallible judgement. Or, at least, almost infallible' (239).

87. 'I was restrained and cautious' (97), he himself confesses.

88. To the question: 'Who are your "heroes"?' Hatziyannidis replies: 'Those people who can combine intellectual agility with kindness' (in the interview to G. Karouzakis in the lifestyle magazine Lifo, 25 January 2007, 16).

89. 'Chance played a major role for me, as it does in the lives of all of us', confessed Hatziyannidis in an interview to L. Papadimitriou, Bimagazino, 7 April 2007, 54.
90. Due to postings to ships and provincial hospitals, Karkavitsas, who was a military doctor, settled only in the last years of his life in the Athens area, in Maroussi (now an Athens suburb). In 1903, when he writes The Archaeologist, he is employed by the Athens Sanitary Services Repository, and resides in Mantzarou Street in Athens; Tsouras 1990, 1199.

91. Arayis 1993b, 49. Argyriou 1993, 53, refers to the 'appreciation of Byzantine Thessaloniki' as one of the roads which led Pentzikis to Christianity.

92. Voyatzaki 2001, 184.

93. 'The first thing which someone should note in Greek fiction between the years 1949 and 1967, is of course, its intense politicization. What could be more natural between a civil war and a dictatorship?' (Moullas 2002, 340).

94. With regard to the main representatives of the generation of the thirties, the following passage from The Lemon Grove

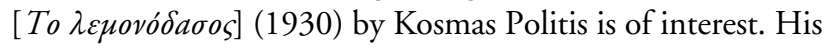
young hero, Pavlos Apostolou, who comes to Delphi to learn the secret of the rhythm and metre of ancient Greek life, declares: 'Archaeology [...] is not a creative science which brings to life the ancient spirit in the findings which once stirred with intense life. It is limited to dissecting a corpse with sadistic curiosity. [...] Ah, poets must also become archaeologists' (15). For the generation of the thirties, there is therefore a great distance dividing the writer-creator and the archaeologist-anatomist. Shortly beforehand, Pavlos Apostolou has spoken of Athens: 'The Parthenon is not only marble. It is clarity, a clean atmosphere and an azure sky, the sea of Aegina, the ethereal and bare mountains, the harmony of substance and spirit. The joy of life [...]' (14). It appears that the generation of the thirties responds more to landscape than monuments, as Savvidis 1992, 20, notes with regard to Seferis, who never expressed any particular interest in archaeology (nor a literary interest in archaeologists), 'despite his rare literary consciousness, [...] his hobby of collecting ancient coins', his friendships with distinguished archaeologists, and the number of pieces he wrote with ancient themes.

95. At the same time Greece was also in an outward-looking period: the Association Agreement with the European Union was signed in 1961. 


\section{REFERENCES}

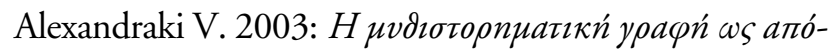

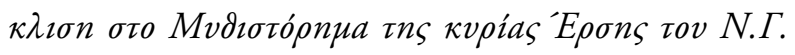
$\prod_{\varepsilon v \tau} \zeta i \kappa n$ (unpublished Ph.D. thesis, University of Athens).

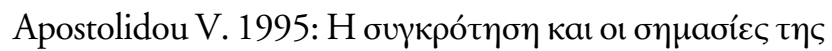

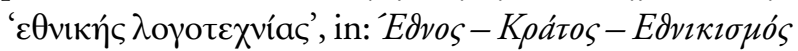
(Athens) 15-39.

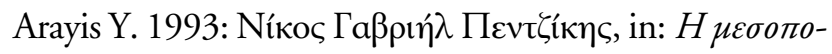

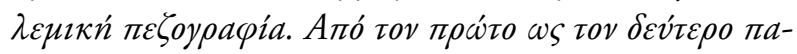

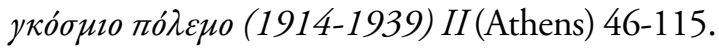

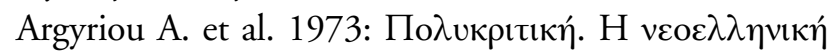

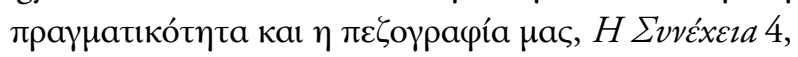
172-79.

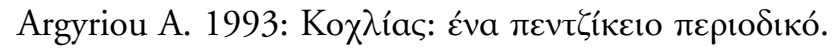

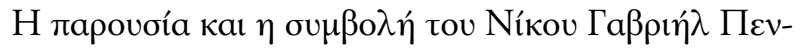

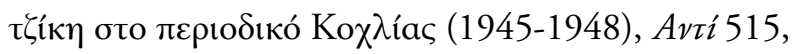
51-54.

Calotychos V. 2003: Modern Greece: a Cultural Poetics (Oxford and New York).

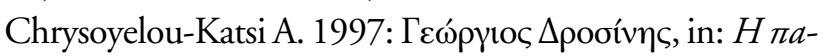

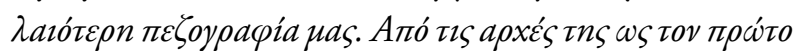

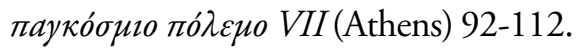

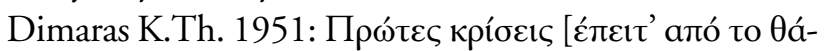
vató tov], Néa Eotía 50, 1371-73.

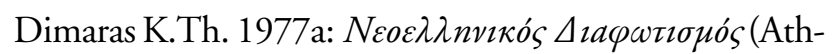
ens).

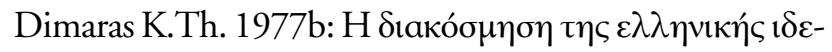

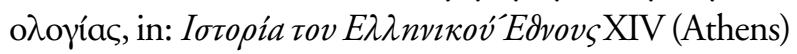
398-409.

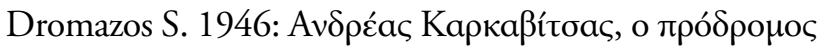

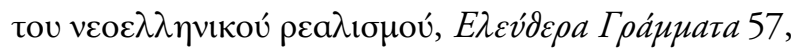
371.

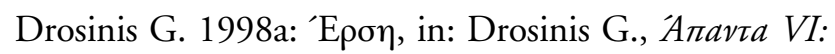

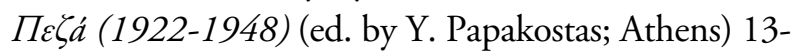
226.

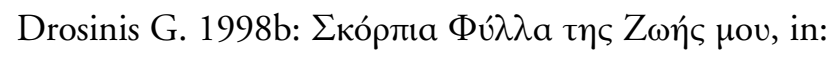
Drosinis G., Aravta VIII (ed. by Y. Papakostas; Athens).

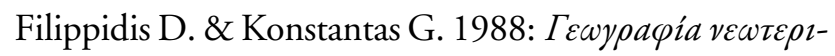
$\kappa n$ (ed. by A. Koumarianou; Athens).

Fostieris A. \& Niarchos Th. 1983: Mıa ouvouı $\lambda$ ía tov

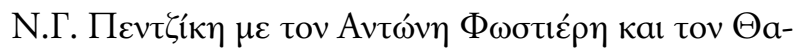

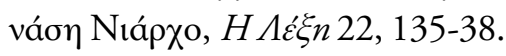

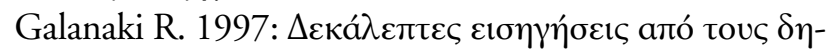

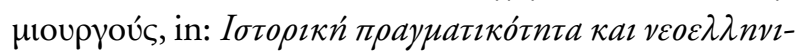

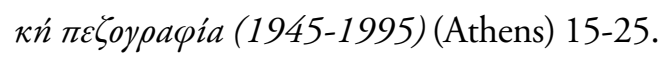

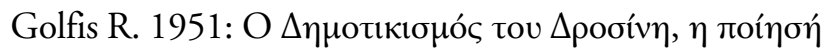

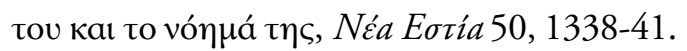

Hamilakis Y. 2007: The Nation and its Ruins: Antiquity, Archaeology, and National Imagination in Greece (Oxford).

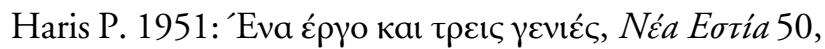
1329-30.

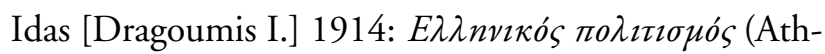
ens).

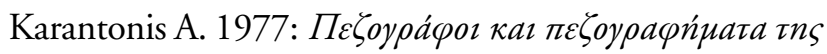
yeviás zov '30 (Athens).

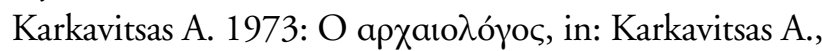
Amavta III (ed. by N. Sideridou; Athens) 1253-1356.

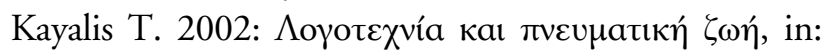

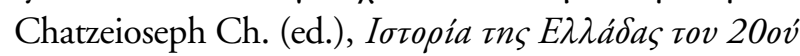

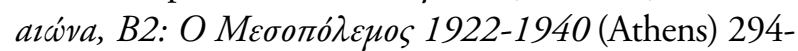
365.

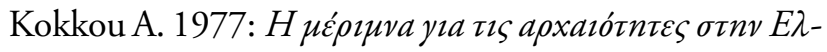

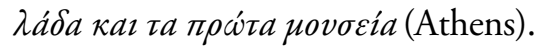

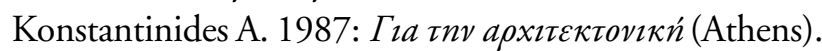

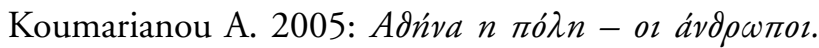

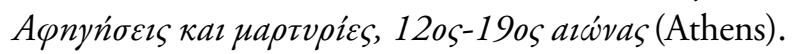

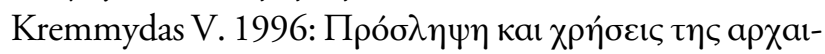

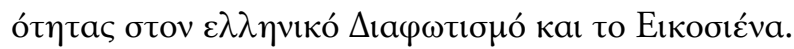

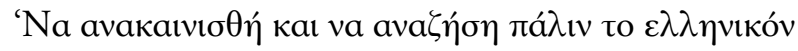
үévoc', O Пoגĩns 29, 24-29.

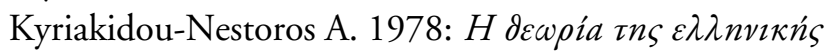

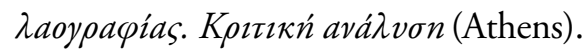

Lambropoulos V. forthcoming: Unbuilding the Acropolis in Greek Literature, in: Vasunia Ph. \& Stephens S. (eds), Classic and National Cultures (Oxford).

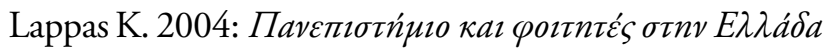

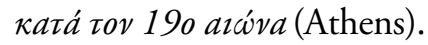

Leontis A. 1995: Topographies of Hellenism: Mapping the Homeland (Ithaca and London).

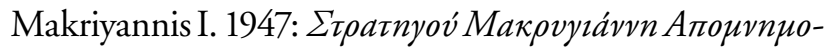
vev́rata (ed. by Y. Vlachoyannis, 2nd edition; Athens).

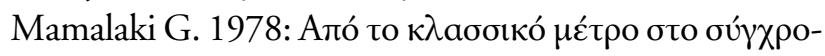

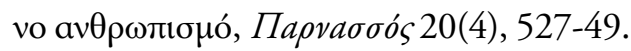

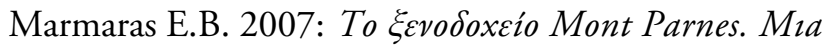

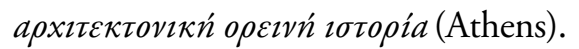

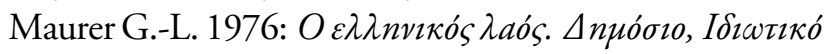

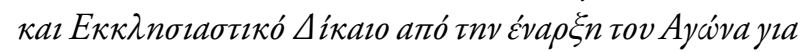

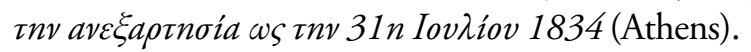




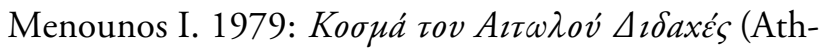
ens).

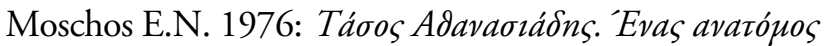

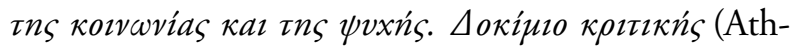
ens).

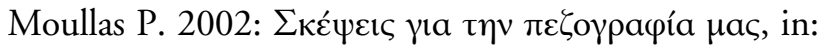

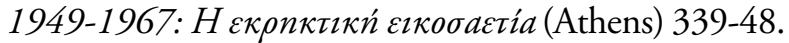

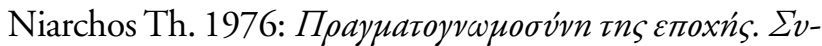
vouıdís (Athens).

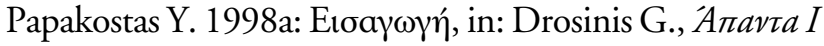
(ed. by Y. Papakostas; Athens) 13-60.

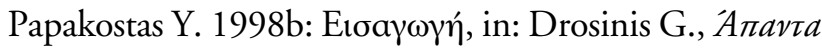

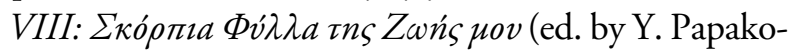
stas; Athens) 16-19.

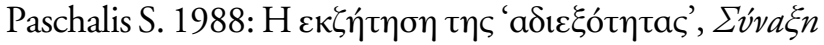
27, 109-15.

Peckham R.S. 2001: National Histories, Natural States: Nationalism and the Politics of Place in Greece (Oxford and New York).

Petrakos V. 1987: H Ev Adńvaıs A

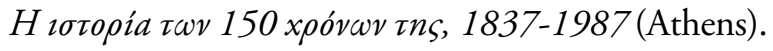

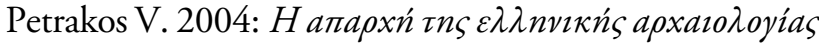

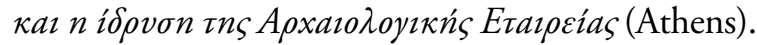

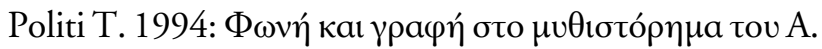

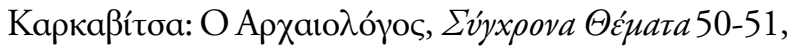
47-52 (repr. in: Politi 1996, 129-54).

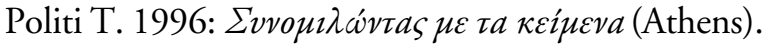

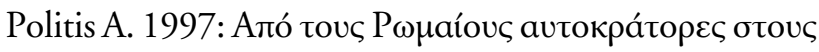

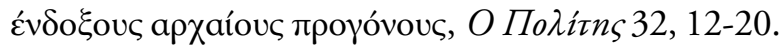

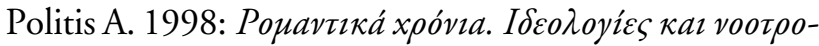

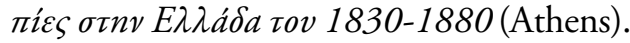

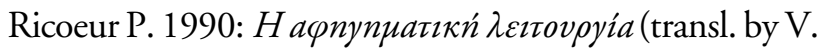
Athanasopoulos; Athens).

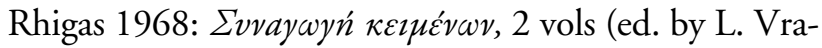
nousis; Athens).

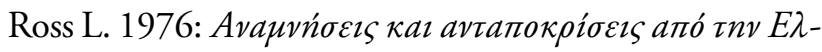
$\lambda a ́ \delta a$ (1832-1833) (ed. by T. Vournas; Athens).

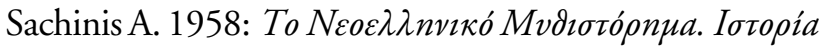

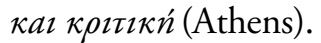

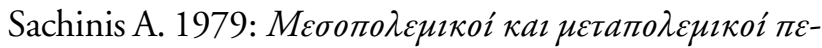

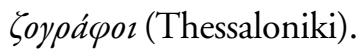

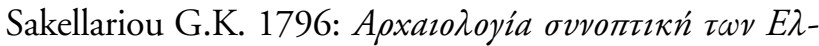

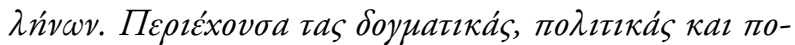

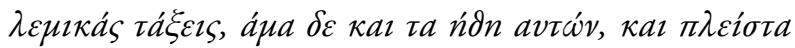

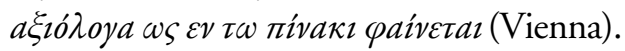

Savvidis Y.P. 1989: Aváotaơ tou $\Delta$ pooívๆ; in: Savvidis

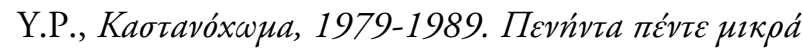

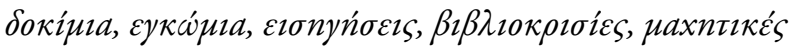

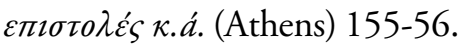

Savvidis Y.P. 1992: Oı a

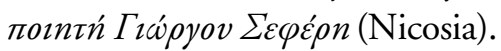

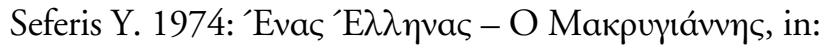

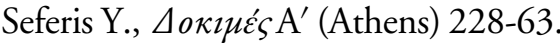

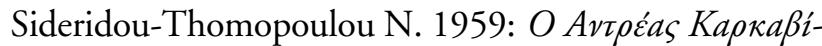

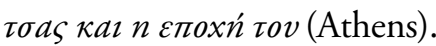

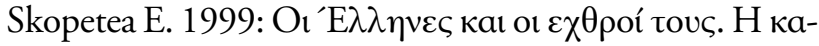

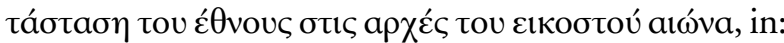

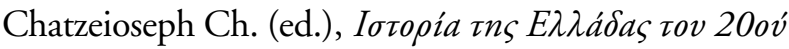

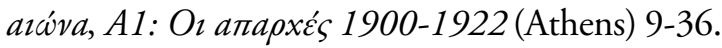

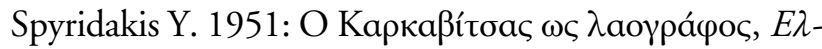
$\lambda$ nviкń $\Delta$ nuıovpyía 8, 45-49.

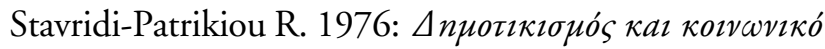

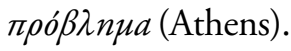

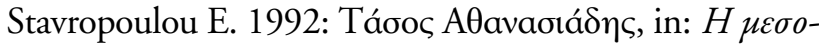

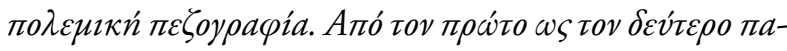

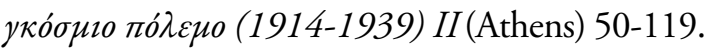

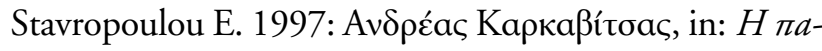

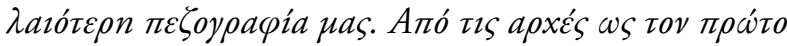

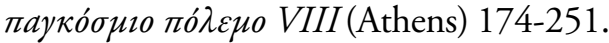

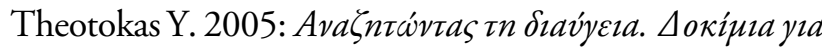

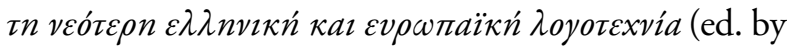
D. Tziovas; Athens).

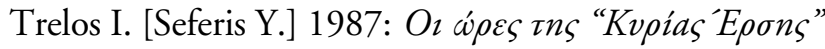
(Athens).

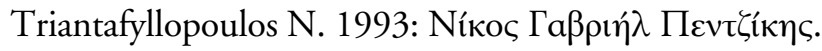

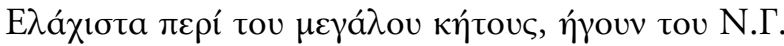

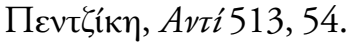

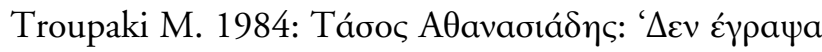

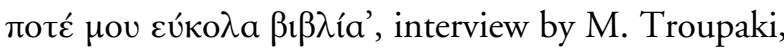
$\triangle \imath a \beta a ́ \zeta \omega$ 105, 64-70.

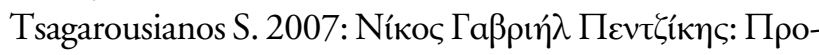

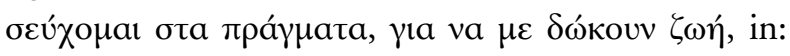

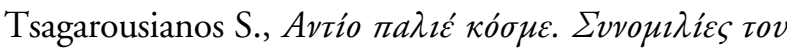

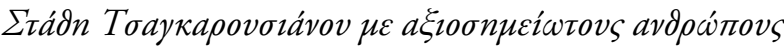
(Athens) 42-64.

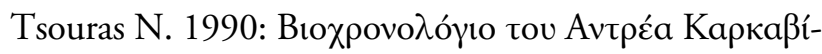

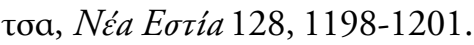

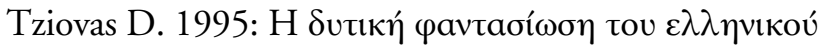

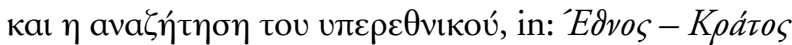

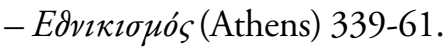

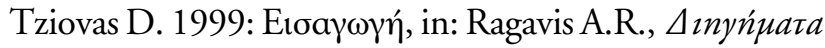
I (ed. by D. Tziovas; Athens) 9-129. 


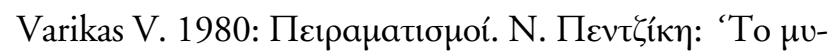

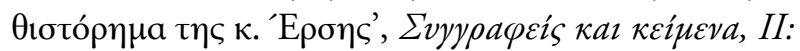
1966-1968 (Athens) 126-30.

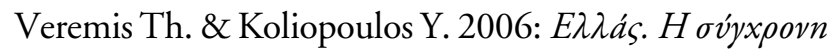

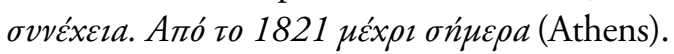

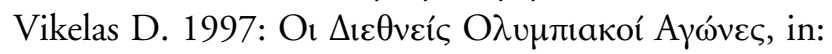
Vikelas D., Aravıa VIII: $\Sigma \dot{v} u \mu \imath \kappa \tau a$ (ed. by A. Angelou; Athens) 124-39.

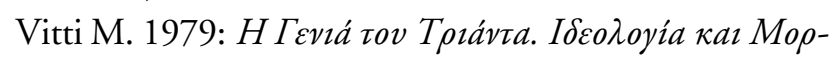
$\varphi n$ (Athens).

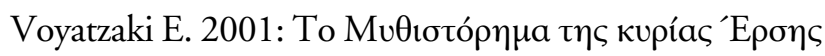

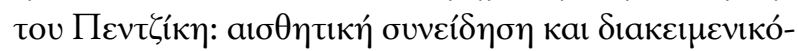

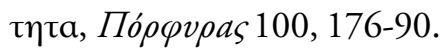

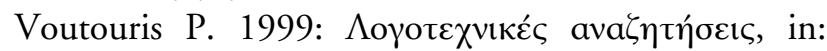

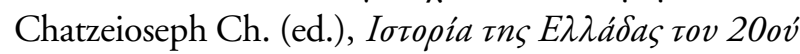

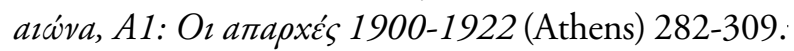

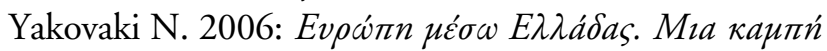

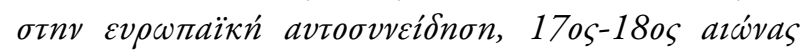
(Athens). 
